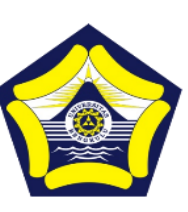

Kinestetik : Jurnal Ilmiah Pendidikan Jasmani

https://ejournal.unib.ac.id/index.php/kinestetik/index

DOI : 10.33369/jk.v5i3.17265

\title{
COLLEGE STUDENT MOTIVATION USES THE COOPERATIVE LEARNING MODEL IN TERMS OF GENDER AND MOTIVATIONAL AUTONOMY THAT AFFECT
}

\author{
Agi Ginanjar ${ }^{*}$, Akhmad Olih Solihin², Dedi Supriadi³, Vicki Ahmad Karisman ${ }^{4}$ \\ ${ }^{1}$ Physical Education, Health and Recreation, STKIP Nahdlatul Ulama Indramayu, Jalan Raya \\ Kaplongan No. 28 Karangampel Indramayu, West Java, 45283, Indonesia \\ ${ }^{234}$ Physical Education, Health and Recreation, STKIP Pasundan, Jalan Permana No.32B \\ Citeureup Cimahi, West Java, 40512, Indonesia
}

\section{Article Info}

Article History :

Received : August 2021

Revised : September 2021

Accepted : September 2021

Available online : September 2021

Keywords:

motivation, college students, cooperative learning, gender, autonomy

\begin{abstract}
Motivation has a very important role for the achievement of college students in participating in the lecture process. Motivation has been found to have a positive influence on cooperative learning. Thus, it is important to see the motivation of college students after attending lectures using the cooperative learning model. The purpose of this study was to examine the effect of the cooperative learning model type Team Games Tournament (TGT) on the motivation of college students, in terms of gender and the autonomy of the motivation that influences it. The research method uses an experimental method with a one group pretestposttest design. The participants in this study were 13 college students in the seventh semester at a university in the eastern part of the province of West Java. The research instrument used the Learning Self-Regulation Questionnaire. The data analysis technique used descriptive statistics and paired samples $t$ test. The results of the study concluded that there was an effect of the TGT learning model on the motivation of college students. There were no differences in motivation between men and women and it was more influenced by intrinsic autonomy in achieving college student motivation. In order to conduct further research related to the findings obtained with more participants. Thus, the findings can be more generalizable.
\end{abstract}

\begin{tabular}{ll}
\hline Corresponding address & : Jl. Raya Kaplongan No. 28 Karangampel \\
Indramayu & \\
*Corresponding email & : agiginanjar@stkipnu.ac.id
\end{tabular}

Indramayu

*Corresponding email : agiginanjar@stkipnu.ac.id
ISSN 2685-6514 (Online)
ISSN 2477-331X (Print) 


\section{INTRODUCTION}

College is one of the levels of education after secondary education which includes several programs and is useful for paying attention to and implementing humanities values through Thridharma College (UU RI No. 12 Tahun 2012). Humanities is an academic discipline that examines the intrinsic humanity (UU RI No. 12 Tahun 2012). Sport is one of the fields of humanities that is useful for developing physical, spiritual and social potential through educational sports (UU RI No. 3 Tahun 2005). Colleges related to sports science have also developed with many special study programs in the field of sports in Indonesia.

The problem that occurs when learning in College is that it does not provide motivation to College students, even though motivation has the most important role to foster interest in learning for College students. The greater the motivation of College students, the greater interest of College students to study (Andoko \& Sukhemi, 2015; Fajarsari, 2020; Nurhayani, 2012). Promoting motivation is the main principle of efficient education and the learning motivation of College students has an influence on the learning outcomes of College students (Tohari et al., 2019). Motivating College students is important to make College students learn optimally (Afriyuandi, 2018). Submission of learning materials must have good motivation between lecturers and College students, College students and College students (Junanda, 2021). In addition, College students must have motivation in attending college. College students need to study seriously based on motivation in attending lectures (Sin, 2017). With College students having motivation is a factor in improving learning outcomes (Nugraha, 2015). This is related to learning in college, lecturers still use conventional models which have the potential to reduce the motivation of college students in the learning process (Junanda, 2021).

Colleges specializing in sports should provide learning experiences that can be useful for College students to become experts in the field of sports by providing motivation (Ginanjar et al., 2021). Moreover, college students in sports programs view positively when given enthusiasm and motivation (Jenkins \& Alderman, 2011). Therefore, in college studies, especially sportsrelated study programs, it is necessary to provide College students with learning experiences that can increase motivation.

Motivation has a very important function because it can determine students' efforts in the learning process (Ginanjar, 2015). Motivation theory has been widely used in various studies, one of which is Self-Determination Theory (SDT) (Deci \& Ryan, 1985). SDT is a continuum from intrinsic motivation (intrinsic regulation), extrinsic motivation (external regulation, introjected regulation, identified regulation, and integrated regulation), to lack of motivation/amotivation (non- 
regulation) (Ryan \& Deci, 2000). Intrinsic motivation comes from autonomous behavior or motivation from within oneself. Extrinsic motivation comes from behavior that is less autonomous so that it is internalized and integrated so that it becomes the basis for autonomous behavior. Meanwhile, the absence of motivation / amotivation means not motivated at all both intrinsically and extrinsically.

One way to overcome existing problems is to use the Cooperative Learning (CL) model. The CL model is a set of alternative instructional methods in which students work together in small groups to help each other learn academic material (Barrett, 2005; Slavin, 1991). In the CL model, it refers to group interaction and social skills of each group member. So that in the CL model students work together to learn, not learn to work together.

In the use of the CL model, there is still much to be researched. The teacher uses the simplest model and the use of CL strategies by teachers and students is not carried out (O'Leary et al., 2015). Teachers who use the CL model identify a number of problems that must be addressed (Ovens et al., 2012). The limited number of studies conducted related to the challenges faced by students in learning using the $\mathrm{CL}$ strategy (Zach \& Cohen, 2012).

In the CL model, there are many types that can be used to be used in the learning process such as: Student TeamsAchievement Divisions (STAD) learning model, Team Games Tournament (TGT) learning model, Team-Assisted Instruction (TAI) learning model, jigsaw learning model, and Group Investigation (GI) learning model (Ginanjar, 2016; Metzler, 2000, 2005). In this study will use the CL model type TGT learning model.

The TGT learning model is a development of the STAD learning model but is more competitive (there is competition within the group) (Ginanjar, 2016). Similarly, the STAD learning model in the TGT learning model, students in one class are placed in groups. All groups were given the same task, allotted time to complete the task with the same time to get the initial score. What distinguishes it In this TGT learning model there are competitions or tournaments in groups to obtain rankings (competitive teams) to be included in inter-group competitions, there are also inter-group tournaments. The tournament was held twice: practicing competing (first) in groups and practicing competing (second) between groups (Ginanjar, 2016).

In Indonesia itself, many studies have been carried out using the TGT learning model. Search results on journals in Indonesia in learning related to sports in the Science and Technology Index (SINTA) with the limitations of accredited journals. There are 22 journal articles that use the TGT learning model that is used in learning that uses sports at the elementary level equivalent (Fahrudin et al., 2020; C. Hidayat et al., 2017; Karim et al., 2017; Supardi, 2018). At the junior high school level and 
equivalent (Agustryani et al., 2020; Arisetiyana et al., 2020; Hasbillah \& Suparman, 2021; Hudah, 2016; Pratama, 2018; Priyanti, 2014). At the high school level or equivalent (Hatanto et al., 2017; A. S. N. Hidayat \& Wardaya, 2015; Kustiawan, 2016; Lambei et al., 2021; Padillah et al., 2020; Saputra, 2018; Syafruddin \& Herman, 2020; Wardana et al., 2020; Wibowo, 2018; Yahya \& Arham, 2021). At the College (Hendrawan, 2014).

From the results of research using the TGT model, 19 journal articles of the TGT learning model were recorded in the psychomotor domain using various sports used. Three journal articles discuss the affective domain. Two articles discuss social skills at the senior high school level (Padillah et al., 2020; Syafruddin \& Herman, 2021). One article discusses motivation at the junior high school level (Arisetiyana et al., 2020).

At the College level itself, it turns out that there is only one research result using the TGT learning model that also leads to the psychomotor realm (Hendrawan, 2014) and it has been a long time since research using the TGT learning model has been conducted in College. This study will be carried out on college students leading to the affective domain of students related to the motivation of college students in participating in learning using the TGT learning model.

This is an interesting thing because at the College level, indeed, lecturers who teach do not use learning strategies using the TGT learning model or other learning models or indeed lecturers of study programs in sports rarely use learning models or prefer conventional models such as the opinion that states that lecturers always teach using conventional models (Junanda, 2021). In line with this, the role of educators/lecturers is still very dominant in improving the development of student learning outcomes in College (Hendrawan, 2014), so that research is rarely carried out related to the recovery of sports study programs related to the use of learning models.

From the whole explanation above, this research will use the CL model type TGT learning model at the College level seen from the motivation of College students who learn to use the TGT learning model. Because motivation has been found to have a positive effect on cooperative learning (Hastie et al., 2011). So the purpose of this study was to examine the effect of the TGT learning model on the motivation of College students. In addition, it will also describe the differences in motivation based on gender and motivational autonomy that affect.

\section{METHODS}

The research method uses an experimental method with a one group pretest-posttest design. Research using this design contains one class that is given a posttest treatment so that the results of the treatment are more 
accurate by comparing the conditions before being given treatment (Ginanjar, 2019).

\section{Participants}

The participants in this study were 13 college students (10 boys and 3 girls) in the seventh semester at the College in the eastern part of West Java province.

\section{Sampling Procedures}

Participants were taken from the seventh semester college student population of 78 college students $(65$ boys and 13 girls) using a systematic sampling technique at multiples of six. Systematic sampling in sampling comes from members of the population who have been given serial numbers. Sampling can be done with odd numbers only (1, 3, 5, 7, 9 to 499), even (2, 4, 6, 8,10 to 500 ), or multiples of certain numbers $(5,10,15,20,25$ to 500$)$ (Ginanjar, 2019).

\section{Materials and Apparatus}

Research instruments related to SDT can be measured using the Learning Self-Regulation Questionnaire (SRQ-L) adapted from the SRQ-L in a medical school course in organ systems (Williams \& Deci, 1996) as many as 14 test items and organic chemistry (Black $\&$ Deci, 2000) as many as 12 test items. This questionnaire concerns the reasons why people study in certain environments such as College. This questionnaire is formed with two subscales: Autonomous Regulation (AR) or the response given can be controlled (external or introjected regulation) and Controlled Regulation (CR) or autonomous (identified regulation or intrinsic motivation). Validation was carried out to College students in the study program as many as 72 College students using 14 test items and after passing several validation stages there were ten test items used. Validation was analyzed using confirmatory factor analysis using IBM SPSS Amos 22 with the results CMIN/DF $=1.92<2$. RMSEA $=0.064$ between $0.05-0.08$ with NFI, PNFI, CFI, IFI, RFI, GFI, AGFI with each of $0.83,0.62,0.91,0.91$, $0.77,0.86$, and 0.78 indicated were accepted so that the structural equation modeling was good with reliability values at AR 0.86 and CR 0.78 (Ginanjar et al., 2021).

\section{Procedures}

The treatment was given eight lectures outside of the pretest and posttest. For the pretest, the data was taken before the college students attended the lectures in the first lecture. While the posttest is given after the last lecture is completed. For lecture programs using the TGT learning model, it can be seen in Table 1 .

Table 1. The lecture program uses the TGT learning model

\begin{tabular}{cl}
\hline Lecture to- & \multicolumn{1}{c}{ Lecture material } \\
\hline 1 & $\begin{array}{l}\text { Passing down volleyball } \\
\text { in pairs with friends }\end{array}$ \\
\hline 2 & $\begin{array}{l}\text { Passing down volleyball } \\
\text { running variation }\end{array}$ \\
\hline 3 & $\begin{array}{l}\text { Passing down volleyball } \\
\text { by bouncing against the }\end{array}$ \\
\hline
\end{tabular}




\begin{tabular}{cl}
\hline Lecture to- & \multicolumn{1}{c}{ Lecture material } \\
\hline wall \\
4 & $\begin{array}{l}\text { Passing down volleyball } \\
\text { with the direction of } \\
\text { passing the ball upwards } \\
\text { continuously. }\end{array}$ \\
\hline 5 & $\begin{array}{l}\text { Passing down volleyball } \\
\text { with a combination of } \\
\text { zigzag movements. }\end{array}$ \\
\hline 6 & $\begin{array}{l}\text { Passing down volleyball } \\
\text { while sitting on the field }\end{array}$ \\
\hline 7 & $\begin{array}{l}\text { Receiving service then } \\
\text { passing down the } \\
\text { volleyball to the target }\end{array}$ \\
\hline 8 & $\begin{array}{l}\text { Receive a smash then pass } \\
\text { under the volleyball to the } \\
\text { target }\end{array}$ \\
\hline
\end{tabular}

\section{Design or Data Analysis}

The data analysis technique uses descriptive statistics to see the average difference (in the form of a graph using the help of Microsoft Excel) (Ginanjar, 2021), based on the difference in the overall SRQ-L gender average and from each SRQ-L sub scale consisting of two subscale. To calculate the difference between pretest and posttest using paired samples $t$ test, the calculation steps for paired samples t test use SPSS according to Ginanjar (2021).

\section{RESULTS}

The results of the difference in mean motivation in terms of gender. The male pretest mean of 49.6 , the male posttest mean of 54.9, and the pretest and posttest gain of 5.3. While the mean pretest for women is 49.33, the mean posttest for women is 54, and the pretest and posttest gains are 4.67, which can be seen in Figure 1.

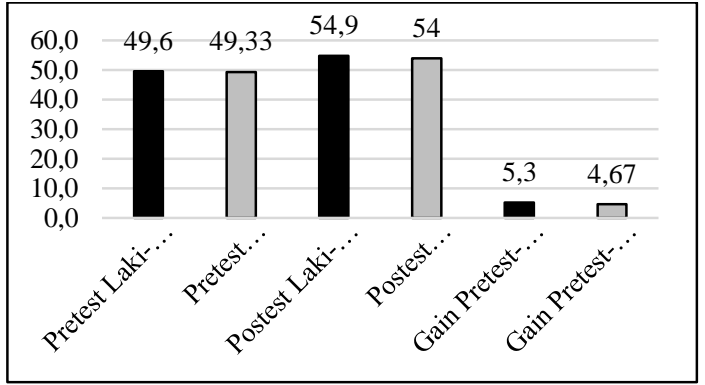

Fig 1. Mean motivation of male and female college students

The results of the difference in mean motivation are seen in the AR and CR motivation subscales as a whole. The mean pretest $\mathrm{AR}$ is 28.15 , the mean posttest AR is 30.15, and the pretest and posttest gains are 2. While the mean CR is 21.38 , the mean $\mathrm{CR}$ is 24.54 , and the pretest and posttest gains are 3.15. can be seen in Figure 2.

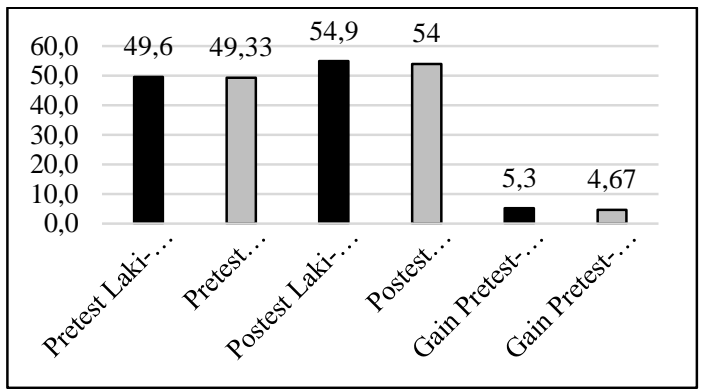

Fig 2. Mean motivation is seen from two sub-scales of motivation

To find out the purpose of this study, which wanted to test the effect of the TGT learning model on the motivation of College students who were analyzed using paired samples $t$ test, the $\mathrm{t}$ value was 2.44 with $\mathrm{df}=12$ and the value of Sig. $0.03(0.03<0.05)$, then the results of the study state that there is an influence of the TGT learning model on the motivation of College students which can be seen in the recapitulation of the 
calculation results of the paired samples $\mathrm{t}$ test in Table 2 .

Table 2. Recapitulation of the calculation results of paired samples $t$ test

\begin{tabular}{lcccc}
\hline Variable & Mean & df & t & Sig. \\
\hline Pretest & 49.54 & \multirow{2}{*}{12} & \multirow{2}{*}{2.44} & $0.03<0.05$ \\
\hline Posttest & 54.69 & & & \\
\hline
\end{tabular}

\section{DISCUSSION}

From Figure 1 which describes motivation by gender. From the results of the pretest and posttest, it can be seen that there are differences in motivation between men and women. However, when viewed from the mean gain for males it is 5.3 and females are 4.67 , so there is only a gain of 0.63 . So it is possible that there is no significant difference in motivation between male and female College students. Therefore, the TGT learning model can be used as a learning model that is highly recommended to be used in the recovery process for college students, both male and female, because they can blend in in a team or group. This is different if the research is carried out on the psychomotor domain which is very likely to differ in the results of achieving the psychomotor domain. Men feel confused when combined with women in a team (Siedentop et al., 2011). Furthermore, women are often marginalized by men in learning sports, especially when it comes to movement skills (Siedentop et al., 2011). Therefore, lecturers should not only look at the psychomotor realm in giving assessments but in affective funds including motivation, so that they can fulfill the gender equality movement that in college students, women in sports can be equal to men (Puspitarini \& Utanto, 2019). Moreover, it has been found that male athletes are more motivated than female athletes (Nopiyanto \& Dimyati, 2018).

From Figure 2, the pretest and posttest results of the $\mathrm{AR}$ and $\mathrm{CR}$ motivation subscales as a whole show that $\mathrm{CR}$ is higher than AR. The CR gain value is 3.15 and the $A R$ gain value is 2 so that the gain is 1.15 . This allows there to be no significance between $\mathrm{CR}$ and AR. However, CR which is an intrinsic autonomy can give higher results than $\mathrm{AR}$ based on the given response or exterinsik autonomy. This can be in line with SDT that a person can be more independent if intrinsically than extrinsically towards his behavior. So this study supports that the formation of student autonomy in sports learning is determined by self-determined motivation (Prusak et al., 2004; Ward et al., 2008), so that they are more likely to adopt new behaviors to long term (Deci \& Ryan, 1985). In addition, it has also been found that intrinsic autonomy is significantly increased in both males and females (Fullmer et al., 2018).

However, in this study, extrinsic autonomy is also a concern because by using the TGT learning model in which there is competition which is characterized by competition within groups and between groups. College students are more motivated to show 
their best results in doing every match either within groups or between groups. Maybe this is the cause that extrinsic autonomy is smaller than extrinsic autonomy, because there is competition and there are College students who win in their groups, and there are teams that lose in inter-group matches.

Field observations showed that when a college student (let's call him Anto) competed in group A, for example, Anto was on a team with another college student who had movement skills above Anto's and lost so he didn't get first place in his group. When he saw other College students in group B with abilities below Anto's, they could become winners and rank first in group B. Anto quipped at the College students by assuming that his fellow College students in his group fortunately did not have better abilities so that they were ranked first. . However, Anto can be proud because when there is a match between groups, his group wins and gets first place. This event may lead to a decrease in motivation. In line with this, students who fail to keep up with competition experience decreased motivation in learning (Campbell, 1974; Fait \& Billing, 1974).

Therefore, it is important for lecturers or lecturers to pay attention to the similarity of abilities in group selection. Do not let one group have good abilities all or vice versa so that the team selection must be heterogeneous. The process of selecting student teams is very important in the CL model, students may be heterogeneous in a team to balance the group, thus enabling fair competition and increasing student motivation (Metzler, 2000, 2005). However, College students still show an increase in motivation in accordance with the intrinsic autonomy that is determined by themselves.

Based on the results of the analysis obtained as a whole. So this study provides support to the results of research which states that the TGT learning model can increase learning motivation (Arisetiyana et al., 2020). In addition, it also supports that the TGT learning model can be used at the College level (Hendrawan, 2014) and provides the latest findings that the TGT model can increase the learning motivation of College students. In addition, motivation theory can be used to create a structure that makes groups realize that the only way a group can achieve learning goals is with all of its members contributing and achieving (Metzler, 2000, 2005).

\section{CONCLUSION}

This study concludes that there is an effect of the TGT learning model on the motivation of College students. There is no difference in motivation between men and women and is more influenced by intrinsic autonomy in the achievement of College student motivation.

The TGT learning model can be used as an alternative for the study program in sports studies in achieving the motivation of College students. In 
order to conduct further research regarding the findings obtained that College students who study using the TGT learning model are more influenced by intrinsic autonomy in a larger number of participants, so that the findings obtained are more generalized.

\section{REFERENCES}

Afriyuandi, A. R. (2018). Hubungan Olahraga Rekreasi Alam Terbuka Dengan Motivasi Belajar Mahasiswa. Jurnal Maenpo:Jurnal Pendidikan Jasmani Kesehatan Dan Rekreasi, 8(1), 54-63.

Agustryani, R., Herliana, M. N., \& Soraya, N. (2020). Pengaruh Model Team Game Tournament ( TGT ) Terhadap Peningkatan Responsibility siswa dalam Pembelajaran Penjas Kelas VIII SMP Negeri 4 Kota Tasikmalaya. Jendela Olahraga, 5(1), 30-34. https://doi.org/10.26877/jo.v5i1.522 5

Andoko, C. Y., \& Sukhemi. (2015). Pengaruh Motivasi Terhadap Minat Mahasiswa Akuntansi untuk Mengikuti Pendidikan Profesi Akuntansi (PPAK). Jurnal Akuntansi Dan Keuangan, 6(1), 652-659. https://doi.org/10.36448/jak.v6i1.56 8

Arisetiyana, F. F., Kartiko, D. C., Indahwati, N., \& Prakoso, B. B. (2020). Motivation And Student Learning Outcomes In Problem Based Learning. JP.JOK (Jurnal Pendidikan Jasmani, Olahraga Dan Kesehatan), 4(1), 1-10. https://doi.org/10.33503/jp.jok.v4i1. 829

Barrett, T. (2005). Effects of cooperative learning on the performance of sixth-grade physical education students. Journal of Teaching in Physical Education, 24(1), 88-102. https://doi.org/10.1123/jtpe.24.1.88

Black, A. E., \& Deci, E. L. (2000). The effects of instructors' autonomy support and students' autonomous motivation on learning organic chemistry: A self-determination theory perspective. Science Education, 84, 740-756.

Campbell, D. N. (1974). On Being Number One: Competition in Education. Phi Delta Kappan, 56(2), 143-146.

Fahrudin, Asmawi, M., Dlis, F., \& Gustiawati, R. (2020). Development Fundamental Movement Learning Model Based on Team Games Tournament (TGT) for Elementary School Children. KINESTETIK: Jurnal Ilmiah Pendidikan Jasmani, 4(2), 164-174. https://doi.org/10.33369/jk.v4i2.125 99

Fait, H., \& Billing, J. (1974). Reassescment of the value of competition. In G. McGlyn (Ed.). Issues in physical education and sports .

Fajarsari, H. (2020). Pengaruh Motivasi dan Persepsi Terhadap Minat Mahasiswa Mengikuti Pendidikan Profesi Akuntansi (PPAK) di Kota Semarang. Jurnal Pamator, 13(1), 30-43.

https://doi.org/10.21107/pamator.v1 3i1.7001

Fullmer, M. O., Wilkinson, C., Prusak, K. A., Eggett, D., \& Pennington, T. (2018). Adolescent Physical Activity and Motivational Profiles While Keeping a Physical Activity Record. Journal of Teaching in Physical Education, 37(1), 1-11. https://doi.org/10.1123/jtpe.20170072

Ginanjar, A. (2015). The Influence of Inquiry Method in Motivating the 
SMP' Student. Jurnal Kependidikan, 45(2), 123-129. https://doi.org/http://dx.doi.org/10.2 $1831 / \mathrm{jk} . v 45 \mathrm{i} 2.7489$

Ginanjar, A. (2016). Implementasi Praktis Model-model Pembelajaran Pendidikan Jasmani. Program Studi Pendidikan Jasmani Kesehatan dan Rekreasi STKIP Nahdlatul Ulama Indramayu.

Ginanjar, A. (2019). Metode Penelitian Kuantitatif dalam Pendidikan Jasmani dan Olahraga. Program Studi Pendidikan Jasmani Kesehatan dan Rekreasi STKIP Nahdlatul Ulama Indramayu.

Ginanjar, A. (2021). Statistika Terapan Dalam Pendidikan Jasmani \& Olahraga: Aplikasi Microsoft Excel \& SPSS. Deepublish.

Ginanjar, A., Mubarok, M. Z., \& Mudzakir, D. O. (2021). "College Students" Motivation after Teaching Using Sport Education Season. International Journal of Human Movement and Sports Sciences, 9(4A), 1-7. https://doi.org/10.13189/saj.2021.09 1301

Hasbillah, M., \& Suparman. (2021). Upaya Meningkatkan Hasil Belajar Passing dalam Permainan Sepak Bola melalui Model Pembelajaran Kooperatif Tipe TGT Siswa SMP Negeri 1 Tanasitolo Kabupaten Wajo. Jendela Olahraga, 6(1), 113120.

https://doi.org/10.26877/jo.v6i1.695 7

Hastie, P., de Ojeda, D. M., \& Calderón, A. (2011). A review of research on sport education: 2004 to the present. Physical Education and Sport Pedagogy, 16(2), 103-132. https://doi.org/10.1080/17408989.20 10.535202

Hatanto, Y., Insanistyo, B., \& Arwin. (2017). Penerapan Model
Pembelajaran Kooperatif Tipe Teams Games Tournaments Untuk Meningkatkan Keterampilan Teknik Passing Kaki Bagian Dalam Permainan Sepak Bola Pada Siswa Kelas X Teknik Informatika SMK Negeri 8 Bengkulu Utara. KINESTETIK: Jurnal Ilmiah Pendidikan Jasmani, 1(2), 68-74. https://doi.org/10.33369/jk.v1i2.346 6

Hendrawan, K. T. (2014). Pengaruh Metode Pembelajaran TGT (Teamgame Tournament) Terhadap Hasil Belajar Forehand Tenismeja Pada Mahasiswa Angkatan 2012- D Program Studi Pendidikan Jasmani Dan Kesehatan STKIP PGRI Jombang. Bravo's Jurnal, 2(1), 4148.

Hidayat, A. S. N., \& Wardaya, H. D. (2015). Peningkatan Pembelajaran Servis Atas Bolavoli Melalui Metode Team games Tournament Kelas XI MIA 5 SMAN 1 Sleman. Jurnal Pendidikan Jasmani Indonesia, 11(2), 130-136. https://doi.org/10.21831/jpji.v11i2.8 190

Hidayat, C., Mulyana, D., \& Juhrodin. (2017). Dampak Model Pembelajaran Cooperative Tipe Team Game Tournament (TGT) Terhadap Kebugaran Dan Perkembanagan Sosial Siswa. Altius: Jurnal Ilmu Olahraga Dan Kesehatan, 6(2), 72-84. https://doi.org/10.36706/altius.v6i2. 8091

Hudah, M. (2016). Pengaruh Model Pembelajaran Team Game Tournament Dan Motivasi Belajar Siswa Kelas VIII Materi Bola Voli di SMP N 1 Karimunjawa 2016. Jendela Olahraga, 1(1). https://doi.org/10.26877/jo.v1i1\%20 Juli.1095

Jenkins, J. M., \& Alderman, B. L. (2011). 
Influence of sport education on group cohesion in university physical education. Journal of Teaching in Physical Education, 30(3), 214-230.

https://doi.org/10.1123/jtpe.30.3.214

Junanda, S. (2021). Tingkat Motivasi Mahasiswa PJKR STKIP Nahdlatul Ulama Indramayu Setelah Mengikuti Sport Education Bola Voli. Jurnal Kependidikan Jasmani Dan Olahraga, 2(1), 36-44.

Karim, D. A., Ginanjar, A., \& Sugiyanto, D. (2017). Pengaruh Model Pembelajaran Team Games Tournament Terhadap Teknik Dasar Passing Bawah Permainan Bola Voli. JSKK: Jurnal Sains Keolahragaan Dan Kesehatan, 2(1), 1-4.

https://doi.org/10.5614/jskk.2017.2. 1.1

Kustiawan, A. A. (2016). Model Pembelajaran Kooperatif Tipe Team Game Tournament (TGT) Untuk Meningkatkan Hasil Belajar Smash Normal Bolavoli Pada Siswa kelas XI SMA Negeri Colomadu Karanganyar Tahun Ajaran 2015/2016. Jurnal Sportif, 2(1), 1335.

https://doi.org/10.29407/js_unpgri.v 2i1.653

Lambei, L. M., Kanca, I. N., \& Wijaya, M. A. (2021). Pengaruh Model Pembelajaran Kooperatif Terhadap Hasil Belajar Atletik Nomor Tolak Ditinjau Dari Kekuatan Otot Lengan. Jurnal Penjakora, 8(1), 2633.

https://doi.org/10.23887/penjakora.v 8i1.30841

Metzler, M. W. (2000). Intructional Models for Physical Education. Allyn and Bacon.

Metzler, M. W. (2005). Instructional Models for Physical Education (2nd ed.). Holcomb Hathaway.
Nopiyanto, Y. E., \& Dimyati, D. (2018). Karakteristik psikologis atlet Sea Games Indonesia ditinjau dari jenis cabang olahraga dan jenis kelamin. Jurnal Keolahragaan, 6(1), 69-76. https://doi.org/10.21831/jk.v6i1.150 10

Nugraha, U. (2015). Hubungan Persepsi, Sikap Dan Motivasi Belajar Terhadap Hasil Belajar Pada Mahasiswa Pendidikan Olahraga Dan Kesehatan Universitas Jambi. Jurnal Cerdas Sifa, 4(1), 1-10.

Nurhayani, U. (2012). Pengaruh Motivasi Terhadap Minat Mahasiswa Akuntansi Untuk Mengikuti Pendidikan Profesi Akuntansi (PPAK). Jurnal Mediasi, 4(1), 59 67.

O'Leary, N., Wattison, N., Edwards, T., \& Bryan, K. (2015). Closing the theory-practice gap: Physical education students' use of jigsaw learning in a secondary school. European Physical Education Review, 21(2), 176-194. https://doi.org/10.1177/1356336X14 555300

Ovens, A., Dyson, B., \& Smith, W. (2012). Cooperative Learning in Physical Education: A research based approach (B. Dyson \& A. Casey (eds.); 1st ed.). Routledge.

Padillah, A., Yudiana, Y., \& Juliantine, T. (2020). The Effect of Cooperative Learning Model and Peer Teaching Model on Social Skills and Volleyball Games Performance. Jurnal Pendidikan Jasmani Dan Olahragaan Olahraga, 5(1), 35-39. https://doi.org/10.17509/jpjo.v5i1.2 2093

Pratama, D. S. (2018). Peningkatan Hasil Belajar Materi Sepak Takraw Dengan Metode Tgt ( Teams Games Tournaments ) Dan Recyprocal Style. Jendela Olahraga, 3(2), 7884. 
https://doi.org/10.26877/jo.v3i2.251 4

Priyanti, E. D. (2014). Upaya Meningkatkan Keterampilan Passing Bawah Bolavoli Dengan Menerapkan Metode Team Game Tournament (TGT). Bravo's Jurnal, 2(3), $135-142$. https://doi.org/10.32682/bravos.v2i3 .275.g216

Prusak, K. A., Treasure, D. C., Darst, P. W., \& Pangrazi, R. P. (2004). The Effects of Choice on the Motivation of Adolescent Girls in Physical Education. Journal of Teaching in Physical Education, 23(1), 19-29. https://doi.org/10.1123/jtpe.23.1.19

Ryan, R. M., \& Deci, E. L. (2000). Selfdetermination theory and the facilitation of intrinsic motivation, social development, and well-being. American Psychologist, 55(1), 6878. https://doi.org/10.1037//0003066x.55.1.68

Saputra, H. (2018). Model Pembelajaran Direct Intruction Dan Model Pembelajaran TGT Teams Games Tournament Terhadap Peningkatan Kemampuan Keterampilan Lay-Up Shoot Dalam Permainan Bola Basket Pada Siswa Kelas XI SMK Pasundan 1 Cianjur. Jurnal Maenpo:Jurnal Pendidikan Jasmani Kesehatan Dan Rekreasio, 8(2), 1631.

https://doi.org/10.35194/jm.v8i2.92 5

Siedentop, D., Hastie, P. A., \& Mars, H. van der. (2011). Complete Guide to Sport Education. Human Kinetics.

Sin, T. H. (2017). Bimbingan Motivasi bagi Mahasiswa pada Pembelajaran Bulutangkis. Jurnal Konseling Dan Pendidikan, 5(2), 92-96. https://doi.org/10.29210/116700 https://doi.org/10.1007/BF00956756 Supardi. (2018). Peningkatan Hasil Belajar Pendidikan Jasmani Melalui
Penerapan Pembelajaran Kooperatif Model Teams Games Tournaments. Bravo's Jurnal, 6(2), 70-74. https://doi.org/10.32682/bravos.v6i2 .835.g591

Syafruddin, M. A., \& Herman. (2020). Pengaruh Model Pembelajaran Kooperatif Tipe TGT ( Team Group Tournament ) Terhadap Kecerdasan Emosi Siswa MAN 2 Makassar. Jendela Olahraga, 5(1), 52-58. https://doi.org/10.26877/jo.v5i1.426 7

Syafruddin, M. A., \& Herman. (2021). Pengaruh Pembelajaran Kooperatif Tipe STAD terhadap Kecerdasan Emosi Siswa SMK N 2 Somba OPU Kabupaten Gowa. Jendela Olahraga, 6(1), 97-105. https://doi.org/10.26877/jo.v6i1.688 9

Tohari, H., Mustaji, \& Bachri, B. S. (2019). Pengaruh Penggunaan YouTube Terhadap Motivasi Belajar Dan Hasil Belajar Mahasiswa. Jurnal Teknologi Pendidikan, 7(1), $1-13$.

https://doi.org/10.31800/jtp.kw.v7n1 .p1--13

UU RI No. 12. (2012). Pendidikan Tinggi. Republik Indonesia.

UU RI No. 3. (2005). Sistem Keolahragaan Nasional. Republik Indonesia.

Ward, J., Wilkinson, C., Graser, S. V., \& Prusak, K. A. (2008). Effects of choice on student motivation and physical activity behavior in physical education. Journal of Teaching in Physical Education, 27(3), 385-398. https://doi.org/10.1123/jtpe.27.3.385

Wardana, M. K. K., Adi, I. P. P., \& Suwiwa, I. G. (2020). Pengaruh Model Pembelajaran Kooperatif Tipe Team Games Tournament (TGT) Terhadap Hasil Belajar Passing Control Sepakbola. Jurnal 
Penjakora, $\quad 7(2), \quad$ 126-134. https://doi.org/10.23887/penjakora.v $7 \mathrm{i} 2.26403$

Wibowo, P. A. (2018). Peningkatan Keaktifan Siswa Dalam Permainan Futsal Melalui Metode TGT Pada Siswa Kelas X Di Sma Selamat Pagi Indonesia Kota Batu. JP.JOK (Jurnal Pendidikan Jasmani, Olahraga Dan Kesehatan), 1(2), 14-23. https://doi.org/10.33503/jpjok.v1i2. 164

Williams, G. C., \& Deci, E. L. (1996). Internalization of Biopsychosocial Values by Medical Students: A Test of Self-Determination Theory. Journal of Personality and Social Psychology, 70(4), 767-779.

Yahya, A. A., \& Arham, S. (2021). Pembelajaran Kooperatif Tipe TGT Dalam Menigkatkan Hasil Belajar Pasing Bawah Permainan Bolavoli Siswa SMAN 2 Bone. Jendela Olahraga, 6(1), 150-157. https://doi.org/10.26877/jo.v6i1.694 8

Zach, S., \& Cohen, R. (2012). Cooperative Learning in Physical Education: A research based approach (B. Dyson \& A. Casey (eds.); 1st ed.). Routledge. 